\title{
Development of DKI Jakarta Regional Fiscal Capacity in 2014-2019
}

\author{
Milla Sepliana Setyowati ${ }^{1}$, Aldy Widiarto ${ }^{2}$, and Indriani ${ }^{3}$ \\ \{milla.s.setyowati@gmail.com ${ }^{1}$, aldywidiarto7@gmail.com², and indri4mf@gmail.comํㅜ
}

Department of Fiscal Administration, Faculty of Administration Science, University of Indonesia I $^{1,2,3}$

\begin{abstract}
The implementation of regional autonomy as a form of strengthening the local economy is by giving regional governments authority to regulate and manage their own matters related to regional government and community interests in accordance with applicable laws and regulations. To improve regional economic capacity, local governments must be able to maximize their regional income. Sources of regional income come from Local Own-source Revenue (LOR), the balancing fund, and other legal PAD. Regional Fiscal Capacity (RFC) is an indicator of each region's financial capacity that reflects the independence of a region. The higher the regional KFD, the more independent the area is from the Balancing Fund provided by the central government. This study aims to analyze the development of the regional financial capacity of DKI Jakarta province in 2014-2019 based on the PMK formula and fiscal capacity theory. This research is a descriptive study that uses a qualitative approach. Regional Fiscal Capacity is strongly influenced by the realization of Regional Revenue. In 2014-2019, DKI Jakarta had the highest Regional Fiscal Capacity Index (RFCI) in Indonesia. This explains that DKI Jakarta is quite independent of the Balancing Fund provided by the Central Government.
\end{abstract}

Keywords: Local Governments, Local Own-source Revenue, Regional Fiscal Capacity

\section{Introduction}

The implementation of fiscal decentralization in Indonesia characterized by the enactment of Act number 22 year 2009 and improved in Act number 32 year 2004 which provides the authority to the autonomous regional head to manage and take care of government affairs and the public interests of the local community following regulations. [1] By the implementation of fiscal decentralization policy which in line with gave greater autonomy to districts and city, has opened opportunities for local governments to maximize the local own-source revenue (LOR). It is a crucial criterion to know and measuring significantly the regional capability in the practice of regional autonomy. To maximize the local own-source revenue, the government is working hard to search the potential revenue sources and optimize it which have charged so far. In maximizing the local own-source revenue, one of the efforts taken by the local government is to maximize the revenue derived from local taxes and regional retribution. These two components are essential and giving the biggest contribution in a revenue structure.

The greater local own-source revenue (LOR), the more Regional Fiscal Capacity (RFC). RFC is a benchmark of the financial capacity of the respective regions. It is needed by every region to run the function and its authority, which is reflected in the capacity of the regional government collecting revenue based on its own resources. 
To make it easier to see the ability of regional finance, the government creates a Map of the Regional Fiscal Capacity. It is a picture of regional financial capacity which is classified based on the regional fiscal capacity index [2]. According to Article 2 paragraph (1) PMK 126/PMK.01/2019, the Map of Regional Fiscal Capacity is used for four things, first of all, is a proposal of Regional Government as a grant recipient, second is for assessment, third is a determination of the amount of counterpart fund, and the last is for other matters which regulated specifically in provisions of regulations.

By seeing at the high achievement of Fiscal Capacity Index of the DKI Jakarta, it can be said that DKI Jakarta condition is already independent and not too dependent on fiscal balancing funding provided by Central Government. Yet, based on the fact, this research aims to analyze the regional fiscal capacity of DKI Jakarta in 2014-2019 which referred to formula according to Minster of Finance Regulation and fiscal capacity theory. This paper is presents a summary of the different research compare with the previous studies, within this paper focus on DKI Jakarta site from 2014 to 2019.

\section{Literature Review}

\subsection{Fiscal Decentralization}

Fiscal decentralization is a budget distribution process from higher to lower government to support the government function or duty and public service in accordance with the number of delegated authorities in government sector. Fiscal decentralization constitutes the authority's delegation in budgeting or financial revenue which was centralized either in administration or its utilization arranged or carried out by central government. [3] The implementation of fiscal decentralization, money should follow function principle is one of principles that have to be noticed and executed. It means any authority submission or delegation the government may bring consequences for necessary budget to execute the authority. The policy of central and regional financial balance is derived from the regional autonomy policy through part of government authority form central to regional. It means the greater authority's delegation the bigger budget will be needed by regional. How decentralization is must to spur the competitiveness among some local governments to be a winner. It may be seen from the better public service. The local government competes to fully understand and provide the best that is required by society, the change of society economic structure with greater society's role which enhance the people's welfare, local people's participation in government. [4]

\subsection{Regional Fiscal Capacity}

The fiscal capacity said Rogers dan Weller is an indicator level of fiscal system development of a country, or a capacity indicator of a more general country. [5] It is a proxy for the government's ability to implement the complex policies. Complementing this statement, Barro stated that Fiscal Capacity in general refers to the relative capacity of local government units / regional equal with local government to generate income from their local own-sources revenue. [6] The Fiscal Capacity Index in operational terms is a ratio or percentage that measures the figure of local revenue per capita which is produced by a province in a given year under the standard hypothetical conditions that specified (for example, each province imposes its own tax on its area at the national average rate or specifying a percentage set by the provincial government itself in the public interest), 
expressed relative to the per capita income that will be generated nationally. The fiscal capacity has become its own uniqueness inherent in the economic level of a province. It is determined by the economic resources, economic activities, and revenue basis of each province. It aims to represent what people and government do, not what they themselves choose to do. Therefore, Fiscal Capacity Index must reflect an ability of economy/finance/revenue which could take by Province. However, Fiscal Capacity Index is not necessarily reflecting a decision of Province/Regional Government in determining the number of revenues that will be enhanced or in what kind of form of its enhancing realization. In line with the statement, Hansen and Perloff said that fiscal capacity is the ability of nation, country, region to increase the revenue which depends on real revenue level in applicable jurisdiction. [7] Another definition delivered by Haryanto, Fiscal Capacity is a component contained in the formula for calculating the General Allocation Fund. It is a part of Balancing Fund in APBN which its allocation based on a formula with the Gap Fiscal concept that is the difference between Fiscal Need and Fiscal Capacity [8].

\subsection{Local Own Revenue (LOR)}

The Regionally generated revenue is revenue that is sourced and collected by regional government. Source of PAD consists of local tax, profits from regionally owned enterprises (BUMD), and other regional income tax. [9] In line with Warsito, local own revenue is regional income sourced from regional tax, the outcome of distribution, the outcome of management of separated regional assets and other legal owned-source revenue in exploring funding in the implementation of regional autonomy as a manifestation of principle of decentralization. [10] .

In addition to what Rahman said, Mardiasmo stated "owned-source revenue is revenue obtained from regional tax sector, retribution, the outcome of regionally owned companies, the outcome of management of separated regional assets, other legal owned-source revenue." [11] Still in line with Mardiasmo's statement, according to Halim, the regional own revenue (PAD) is "all revenues that come from its own economic source of the region. [12] According to Halim and Nasir, owned-source revenue is revenue that obtained by region and collected based on applicable regulations.

\section{Method}

The research uses qualitative approach. This method is considered to be able to generate more valid, comprehensive, reliable and objective result. This research analyzes the development of Regional Fiscal Capacity in DKI Jakarta in 2014-2019 by examining the realization of Regional Revenues and certain expenditures of DKI Jakarta. In this study, qualitative approach explain about the analysis of development of Regional Fiscal Capacity in DKI Jakarta. The primary data in this research are obtained through field studies, namely indepth interviews. In-depth interviews are carried out with informants related to the study, They were conducted with informants related to the research, such as Subdivision of Strategic Planning and Revenue (Regional Income Agency of DKI Jakarta Province), Controlling section of Regional Tax Revenue Performance (Regional Income Agency of DKI Jakarta Province), and also the academics.

The information source of secondary date in this research is obtained through statistik.jakarta.go.id, the Statistics Central Agency, Local Government Finance Office of DKI 
Jakarta Province, DJPK. Literary studies are obtained from book, journal, law and regulations, scientific work, such as thesis and other similar data related to the research which gained form internet. The informants are given freedom to answer questions according to their opinions since the authors do not limit the answers. Secondary data in this study are obtained through literature studies, such as books, journals, legislation, scientific studies such as thesis, journals, and other similar data related to the study. This study applies qualitative data analysis. The data obtained through field studies are coded to produce a concept related to the study. Then, the concept produced is analyzed using regional fiscal capacity indicators from Barro. Data are obtained through field study that further analyzed the development of regional fiscal capacity.

\section{Result And Discussion}

DKI Jakarta is the owner of the largest regional fiscal capacity along with its development from 2014-2019. The reason DKI Jakarta becomes the province with the largest regional fiscal capacity value is, indeed, the local revenue of DKI Jakarta that is undoubtedly huge compared other provinces. In 2014-2019 the local revenue growth of DKI Jakarta tended to have an increasing graph. Hereby of course, the increasing of regional income of DKI Jakarta, it will also increase its regional fiscal capacity. The Regional income of DKI Jakarta in 2014-2019 as follows.

Table 1. Regional Income of DKI Jakarta 2014-2019 (in trillion)

\begin{tabular}{lcccccc}
\hline \multicolumn{1}{c}{ Regional Income } & $\mathbf{2 0 1 4}$ & $\mathbf{2 0 1 5}$ & $\mathbf{2 0 1 6}$ & $\mathbf{2 0 1 7}$ & $\mathbf{2 0 1 8}$ & $\mathbf{2 0 1 9}$ \\
\hline LOR & 31,27 & 33,68 & 36,88 & 43,90 & 44,57 & 42,62 \\
a. Local Tax & 27,05 & 29,07 & 31,61 & 36,50 & 38,12 & 36,89 \\
b. Retribution & 0,51 & 0,45 & 0,67 & 0,62 & 0,68 & 0,54 \\
c. Segregated Regional & 0,46 & 0,52 & 0,30 & 0,48 & 0,53 & 0,59 \\
Assets & & & & & & \\
d. Other legal LOR & 3,24 & 3,62 & 4,29 & 6,28 & 5,21 & 4,6 \\
Balacing Fund & 9,67 & 5,88 & 15,27 & 18,96 & 21,40 & 19,34 \\
a. DBH & 9,58 & 5,88 & 12,38 & 16,84 & 18,26 & 16,22 \\
b. DAU & 0,08 & 0 & 0 & 0 & 0 & 0 \\
c. DAK & 0 & 0 & 2,88 & 2,12 & 3,13 & 3,12 \\
& & & & & & \\
Other Legal Revenues & 2,87 & 4,63 & 1,62 & 1,95 & 0,05 & 2,84 \\
$\quad$ Total & 43,81 & 44,19 & 53,77 & 64,81 & 66,02 & 64,80 \\
\hline
\end{tabular}

Source: statistik.jakarta.go.id, Badan Pusat Statistik, Regional Financial Management Office of DKI

Jakarta, DJPK

The Regional Revenue of DKI Jakarta originating from Local own-source Revenue (LOR), Balancing Fund, and other legal revenues which increase and decrease in 2014-2019. If it can be seen from total regional revenue of DKI Jakarta in 2014-2019 increased and decreased in 2019. In 2014-2015, the regional revenue of DKI Jakarta increased around $0.38 \mathrm{~T}$ or as much as $0.8 \%$. For 2016, an increase of $9.58 \mathrm{~T}$ or $21 \%$ of revenue in 2015 . Then for 2017 , Regional Revenues experienced an increase of $11.04 \mathrm{~T}$ or $20 \%$ from the previous year. While in 2018 , it was not too different from revenue in 2017 which only experienced an increase of $1.21 \mathrm{~T}$ or $1.86 \%$. For 2019 , income tended to fall by $1.22 \mathrm{~T}$ or $1.84 \%$.

According to PMK 126 /PMK.07/2019 article 5 (1) the Regional Fiscal Capacity Index (Provincial) is calculated based on 2 variables, namely the Regional Fiscal Capacity 
(Province) to be calculated, and the average Provincial Fiscal Capacity in Indonesia. The range of Regional Fiscal Capacity Index (IKFD) is adjusted annually by the Ministry of Finance. The following is the range of Provincial Fiscal Capacity Index (IKFD) and its categories.

Table 2. Regional Fiscal Capacity Index Category (Provincial) per Year 2014-2019

\begin{tabular}{ccccc}
\hline IKFD 2014-2016 & IKFD 2017 & IKFD 2018 & IKFD 2019 & Kategori KFD \\
- & IKFD $<0,36$ & IKFD $<0,351$ & IKFD $<0,304$ & Very Low \\
IKFD $\leq 0,5$ & $0,36 \leq$ IKFD & $0,351 \leq$ IKFD & $0,304 \leq$ IKFD & Low \\
& $<0,54$ & $<0,530$ & $<0,445$ & \\
$0,5<$ IKFD $<1$ & $0,54 \leq$ IKFD & $0,530 \leq$ IKFD & $0,445 \leq$ IKFD & Moderate \\
& $<1$ & $<0,823$ & $<0,808$ & \\
$1 \leq$ IKFD $<2$ & $1,02 \leq$ IKFD & $0,823 \leq$ IKFD & $0,808 \leq$ IKFD & High \\
& $<2$ & $<1,531$ & $<1,564$ & \\
IKFD $\geq 2$ & IKFD $\geq 2$ & IKFD $\geq 1,531$ & IKFD $\geq 1,564$ & Very High \\
\hline \multicolumn{5}{l}{ Source: PMK 54/PMK.07/2014, PMK 33/PMK.07/2015, PMK 37/PMK.07/2016, PMK }
\end{tabular}

119/PMK.07/2017, PMK 107/PMK.07/2018, PMK 126/PMK.O1/2019.

DKI Jakarta Province's Fiscal Capacity Index is very high compared to any other province in Indonesia. DKI Jakarta's RFC from 2014-2019 always enter the very high category of RFC (RFC $\geq 1,564$ ). In the calculation of DKI Jakarta RFC in 2014-2017 there is a difference by not including the allocation of special autonomy funds, and provincial transfers. Whereas in 2017-2019 the variables needed in calculating the Regional Fiscal Capacity of DKI Jakarta in 2017-2019 are local own source revenue, Balance Funds, Other Legal Revenues, Cigarette Taxes, Non-Physical DAK (excluding PNSD Teacher Professional Allowance Funds, and Additional PNSD Teacher Income), Personnel expenditures, and Interest Expenditures. The difference in the formula for calculating Regional Fiscal Capacity before and after in 2017 did not cause a significant change in the Regional Fiscal Capacity Index of DKI Jakarta.

Keep in mind that the fiscal capacity index is not necessarily directly proportional to the value of a region's capacity. The index can be considered as a gap between the fiscal capacity values of one province to another. The greater the index of a province, the greater the gap in the value of the fiscal capacity of the region compared to the average of other provinces. It is possible that the relative fiscal capacity index increases each year but the value of a province's fiscal capacity decreases. This is caused by the average provincial fiscal capacity in Indonesia is much lower. As a result, the provincial fiscal capacity index of a province is high (increasing), even though the provincial fiscal capacity is decreasing.

As explained earlier, there is a formula for calculating regional fiscal capacity in PMK Number 37/PMK.07/2016, and PMK Number 126/PMK.07/2019. Further it will be discussed the fiscal capacity of the DKI Jakarta province annually to see the development of the DKI Jakarta's fiscal capacity from 2014-2019.

Regional Fiscal Capacity Calculation in the 2014-2019 has different calculation formulas for before and after in 2017. The difference in the calculation formula is determined by the Ministry of Finance as the institution that issues the Minister of Finance Regulation (PMK). For the calculation of Regional Fiscal Capacity in 2014-2016, having the same calculation formula is represented by the Regional Fiscal Capacity calculation formula contained in PMK Number 37/PMK.07/2016. [14] While for the calculation of Regional Fiscal Capacity in 2017 2019, having the same calculation formula is represented by the Regional Fiscal Capacity calculation formula contained in PMK Number 126/PMK.07/2019. The change in the formula for calculating Regional Fiscal Capacity by the Ministry of Finance through PMK is because 
the Ministry of Finance wants to update the formula for calculating Regional Fiscal Capacity so that the results obtained from the formula for calculating the new Regional Fiscal Capacity can be more relevant to reflect the value of the Regional Fiscal Capacity of each Province in Indonesia.

Calculation of the Regional Fiscal Capacity of DKI Jakarta before 2017 did not require Special Autonomy Funds, and Provincial Transfers. Because according to Law No.35 Year 2008, only Aceh, Papua and West Papua Provinces receive the Special Autonomy Fund, and the Additional Infrastructure Funds. Provincial transfers are not needed in the calculation of the DKI Jakarta Regional Fiscal Capacity before 2017 because the DKI Jakarta province is a special region that is different from other provinces. DKI Jakarta does not do Provincial Transfers.

Calculation of Regional Fiscal Capacity of DKI Jakarta Province in 2017-2019 there are several variables that are not needed by DKI Jakarta. DKI Jakarta does not need the variable Tobacco Excise Profit-sharing Funds, Revenue Sharing Funds of SDA, Reforestatation Funds, Special autonomy funds, Physical DAK of Additional Infrastructure Funds, DIY Privileges Funds, Grant Expenditures for New Autonomous Regions, and Revenue Sharing Expenditures. This is based on the detailed allocation of the Revenue Sharing Fund each year which states that DKI Jakarta does not get Tobacco Excise profit-sharing fund, and SDA sharing profit fund, Sharing profit fund of Reforestation Funds. Furthermore, based on the details of the DAK allocation per year, it states that DKI Jakarta does not get Physical DAK. For the Special Autonomy Fund, and the Additional Infrastructure Fund according to Law No. 35 Year 2008, the only provinces of Aceh, Papua and West Papua received the funds. Furthermore, the DIY Privileged Fund is not needed in calculating DKI Jakarta's Fiscal Capacity because the variable is only devoted to DIY. Grant spending for the New Autonomous Region is also not needed in the calculation because DKI Jakarta is not a new autonomous region. Then for Revenue Sharing is not needed in the calculation because DKI Jakarta is a special area that does not do profit-sharing shopping.

For simplicity, the following formula for calculating Regional Fiscal Capacity for DKI Jakarta in 2014-2016:

$$
\mathrm{REC}=\frac{(\mathrm{LR}+\mathrm{GAF}+\mathrm{DBH}++\mathrm{LP})-\mathrm{BP}}{\text { total of Poor Population }}
$$

While the formula for calculating the Regional Fiscal Capacity of the DKI Jakarta province for 2017-2019 is as follows:

RFC Province $=\mathrm{LR}+$ Balancing Fund $+\mathrm{LP}-($ Cigarette Tax + DAK non Physical (not including Proffesional Allowance for Regional Teachers of Civil Servant and Additional Income Fund for Regional Teachers of Civil Servant) + personnel expenditure + Interest Expenditures)

$\begin{array}{ll}\text { Note: } & =\text { Fiscal Capacity } \\ \text { FC } & =\text { Local Revenue } \\ \text { LR } & =\text { General Allocation Fund } \\ \text { GAF } & =\text { DBH }+ \text { DAU + DAK } \\ \text { Balancing Fund } & =\text { Other Legal Revenue } \\ \text { LP } & =\text { Personnel expenditure } \\ \text { PE } & \end{array}$


Based on the calculation of regional fiscal capacity according to PMK Number 37/ PMK.07/2016 the results of calculations for the regional fiscal capacity of DKI Jakarta province in 2014 amounted to 75,583,226.34. Can be seen from regional fiscal capacity calculation data in 2014, the very dominant variable is derived from LR. LR in 2014 accounted for at least $71 \%$ of regional income which is the fulcrum in calculating the regional fiscal capacity of the DKI Jakarta province. By this, it can be seen that the role of LR is very large in the calculation of the regional fiscal capacity of the DKI Jakarta province, although non-LR revenue also plays a role in the calculation of the fiscal capacity of the DKI Jakarta province. Whereas personnel expenditure in 2014 was classified as low, at only $12.6 \mathrm{~T}$. This also had a role in calculating regional fiscal capacity. Due to the relatively low employee expenditure in 2014, this made Jakarta Capital Province's fiscal capacity in 2014 was high, even though the number of poor people this year is relatively larger compared to subsequent years.

In 2015 DKI Jakarta Province's Regional Fiscal Capacity decreased to 72,937,857.7. Local Revenue (LR) increased by $2.41 \mathrm{~T}$ compared to the previous year. However, starting in 2015 DKI Jakarta has not received a Balancing Fund in the form of a General Allocation Fund from the Central Government. The Revenue Sharing Fund also decreased by $3.7 \mathrm{~T}$. However, revenue from other legal income increased by $1.76 \mathrm{~T}$. If the total revenue of DKI Jakarta in 2015 was $44.19 \mathrm{~T}$, which means an increase of $3.8 \mathrm{~T}$ from the previous year. The poor population was also successfully reduced by 44,120 people. However, in 2015 employee expenditure which here is a deduction to calculate Regional Fiscal Capacity increases rapidly, amounting to $4.7 \mathrm{~T}$. This makes the burden of DKI Jakarta increases, which causes the Fiscal Capacity of the DKI Jakarta Province to decrease, despite total revenue go up and the poor go down. The main reason for the decline in the 2015 DKI Jakarta Regional Fiscal Capacity is that the increase in regional income is not as large as the increase in personnel expenditure in DKI Jakarta Province.

DKI Jakarta's Regional Fiscal Capacity in 2016 increased from the previous year, which was valued at $81,717,810.49$. The Local Revenues increased quite large, which increased by 3.2 T. In 2016 DKI Jakarta, the same as the previous year did not get a General Allocation Fund (GAF), but the Revenue Sharing Funds (DBH) from the central government increased significantly, namely by $6,5 \mathrm{~T}$. While for other incomes dropped quite large, which is worth 3.01 T. If it added up, the regional income of the Province of DKI Jakarta is $53.77 \mathrm{~T}$. As for personnel expenditure and the poor population increased in 2016, the personnel expenditure rose by $2.05 \mathrm{~T}$, then the poor population increased by 17,170 people. Although expenditure for staff and the poor increased in 2016, the regional fiscal capacity of DKI Jakarta this year is relatively large compared to the previous year. This is caused by the increase in personnel and poor population spending successfully surpassed by the increase in Regional Revenue of DKI Jakarta.

In 2017 the formula for calculating Regional Fiscal Capacity changes, in 2017-2019 the calculation of Regional Fiscal Capacity uses PMK Number 126 /PMK.07/2019. In the calculation formula in PMK Number 126 /PMK.07/2019 the variables used are more than the previous formula. In this formula there are additional variables to calculate the Fiscal Capacity of the DKI Jakarta Province, namely Cigarette Tax and Non-Physical DAK. Cigarette Tax is added as a deduction variable in the calculation of Regional Fiscal Capacity because the use of the Cigarette Tax has clearly been allocated, namely for the needs of the Health BPJS. Therefore, the Cigarette Tax must be spent in the regional income of DKI Jakarta in finding Regional Fiscal Capacity by becoming a deduction variable in its calculation formula. While Non-Physical DAK is used as a deduction variable because the funds have been specifically 
allocated for School Operational Costs (BOS), Health Operational Assistance, Population Administration Service Funds, and others (except PNSD teacher additional and allowances). Besides, in this formula the variable number of poor people is eliminated. With the elimination of the variable number of poor people, this formula is more in line with the opinion of experts who do not include the poor population in the calculation of regional fiscal capacity.

Regional Fiscal Capacity of DKI Jakarta Province in 2018 decreased compared to the previous year, which was $40.46 \mathrm{~T}$. There was an increase and decrease in several variables, Local Revenue (LR) only experienced an increase of 0.67 T. $2.44 \mathrm{~T}$ and others legal revenues decreased by $1.9 \mathrm{~T}$. For the total regional income if it is combined experience increasing by $1.21 \mathrm{~T}$. While for the variable reduction in cigarette tax decreased by $0.13 \mathrm{~T}$. However, NonPhysical DAK increased by $0.06 \mathrm{~T}$. Personnel expenditure also experienced a significant increase, which was $3.02 \mathrm{~T}$, and interest spending rose by $0.02 \mathrm{~T}$. If added up the reduction variable has increased from the previous year, which amounted to $2.97 \mathrm{~T}$. This is what causes the Fiscal Capacity of the DKI Jakarta Region in 2018 decreased, which is caused by the ratio of the increase in regional revenue of DKI Jakarta in 2018 not as much as the ratio of the increase in staff and interest expenditure.

In 2019 the Regional Fiscal Capacity of the DKI Jakarta Province experienced a very large decline, namely to $37.53 \mathrm{~T}$. This is due to a decrease in regional income, but an increase in staff and interest expenditure. Local Own Revenue (LOR) which is a core variable Regional Fiscal Capacity decreased by $1.95 \mathrm{~T}$. Balancing funds also fell by $2.06 \mathrm{~T}$ from the previous year. While other income increased by $2.79 \mathrm{~T}$. For the total Regional Revenue of DKI Jakarta in 2019 decreased by $1.22 \mathrm{~T}$. For the reduction variable, cigarette tax increased by $0.16 \mathrm{~T}$, then Non-Physical DAK increased by 0.02 T. Personnel expenditure, which has always risen every year this time increased by $1.51 \mathrm{~T}$, as well as interest expenditure which rose by $0.02 \mathrm{~T}$. For the total deduction of the calculation of Regional Fiscal Capacity increased by $1.71 \mathrm{~T}$.

Calculation of Regional Fiscal Capacity according to the theory of fiscal capacity (Barro, 2002) generally refers to the relative ability of local government /units of the same level as local governments to generate revenue from their own regional revenue sources. Thus, according to Barro, the regional fiscal capacity is assessed only through Local Own Revenue (LOR).

Table 3. Regional Fiscal Capacity of DKI Jakarta in 2014 - 2019 According to Barro (2002)

\begin{tabular}{ccccccc}
\hline Year & 2014 & 2015 & 2016 & 2017 & 2018 & 2019 \\
RFC & 31,27 & 33,68 & 36,88 & 43,90 & 44,57 & 42,62 \\
\hline \multicolumn{5}{l}{ Source: Processed from Local Government Finance Office of DKI Jakarta Province }
\end{tabular}

When compared with the development of DKI Jakarta's Regional Fiscal Capacity based on the PMK formula, RFC according to Barro is relatively increasing every year, although there is a decrease in 2019. The difference in this development is due to differences in formulas, according to the Regional Fiscal Capacity according to the Regional Revenue. While the calculation of the Regional Fiscal Capacity based on PMK does not originate only from the Local Own Revenue (LOR), but there are other variables as deductions such as personnel expenditure and so on. In line with the opinion of the experts that fiscal capacity is determined by the economic resources, economic activities, and income bases of each province. Fiscal capacity shows the ability of a nation, state, and region to increase income, which basically depends on the level of real income of the region in applicable jurisdiction. 


\section{Conclusions}

The development of DKI Jakarta's Regional Fiscal Capacity in 2014 - 2019 based on the Minister of Finance Regulation is fluctuating. In 2014 to 2015 DKI Jakarta's Regional Fiscal Capacity decreased because the increase in regional income was not proportional to the increase in personnel expenditure. However, in 2015 to 2016 the Regional Fiscal Capacity of DKI Jakarta has increased because regional income in 2016 rose quite large, with an increase exceeding the level of increase in personnel expenditure in 2015. In 2017 - 2019 Regional Fiscal Capacity has decreased each year due to an increase in regional income not proportional to an increase in personnel and interest expenditure. Meanwhile, the Regional Fiscal Capacity of DKI Jakarta in 2014 - 2019 according to Barro, which was assessed based on Local own Revenues showed an increase until 2018. The decline in LOR only occurred in 2019. The high fiscal capacity of DKI Jakarta shows the ability of regions to increase revenues that depend on the level of real income in DKI Jakarta.

\section{References}

[1] Republik Indonesia, 2004, Undang-Undang Nomor 32 Tahun 2004 tentang Pemerintah Daerah.

[2] Kementerian Keuangan Republik Indonesia. (2019) Peraturan Menteri Keuangan PMK 126/PMK.07/2019 tentang Peta Kapasitas Fiskal Daerah.

[3] Simanjuntak, Robert. (2002). Transfer pusat ke daerah: konsep dan praktik di beberapa negara (dana alokasi umum: konsep dan prospek di era otonomi daerah).

[4] J. Samoff. (2001) "Decentralisation: The Politics of Interventiosm" dalam Kent Eaton, "Political Obstacles to Decentralisation: Evidence from Argentina and the Philippines”, Development and Change, Vol.32.

[5] Rogers, Chrissie, Sussie Weller. 2013. Journal of Public Policy : Income taxation and the validity of state capacity indicators.

[6] Barro, Stephen M. 2002. Macroeconomic Versus RTS: Measures of Fiscal Capacity: Theoretical Foundations and Implications for Canada. IIGR: Queen's University.

[7] Hansen, Alvin H. dan Harvey S. Perloff. 1944. State and Local Finance in The National Economy. United State of America: The Vail Ballou Press.

[8] Haryanto, Joko Tri. 2006. "Kemandirian Daerah" Sebuah Perspektif Dengan Metode Path Analisys.

[9] Warsito. 2011. Pajak Daerah dan Retribusi Daerah. Jakarta: Semesta Media.

[10] Rahman, Herlina. 2005. Pendapatan Asli Daerah. Jakarta: Arifgosita

[11] Mardiasmo. 2002. Otonomi dan Manajemen Keuangan Daerah. Yogyakarta: Penerbit Andi.

[12] Halim, Abdul, 2012. Akuntansi Sektor Publik Akuntansi Keuangan Daerah Edisi Keempat. Jakarta: Salemba Empat

[13] Halim, Abdul dan Nasir. 2004. Manajemen Keuangan Daerah, Edisi Revisi. Yogyakarta: UPP AMP YKPN.

[14] Kementerian Keuangan Republik Indonesia. (2016) Peraturan Menteri Keuangan PMK 37/PMK.07/2016 tentang Peta Kapasitas Fiskal Daerah. 